\title{
Effect of dietary supplementation (propolis and/or digestarom) on some blood indexes in broiler chicks under chronic heat stress
}

\author{
Hasanain Shawqi Hasan \\ Hasseba Abbas Omran \\ Department of Pathology and Poultry Diseases, College of Veterinary Medicine, University of Baghdad, Iraq. \\ Corresponding Author Email: Hasanain.shauqi90@gmail.com
}

(Received 9/9/2017, Accepted 22/12/2017)

\begin{abstract}
This study was conducted to determine the adverse effects of high temperature on some blood parameter of broiler chickens reared under high environmental temperature and evaluating the adding of (propolis and/or digestarom) on diet, three hundred, one-day-old broiler chicks (Rose 308) were distributed equally into two separated room, thermoneutral (TN) groups and heat stressed (HS) group $\left(33 \pm 2{ }^{\circ} \mathrm{C}\right)$ all over the experiment (42) day. These groups subdivided in to five treated groups (30) chick each. They offered a basal diet supplemented with either propolis $(2 \mathrm{~g} / \mathrm{kg}$ of diet), or digestarom $(150 \mathrm{mg} / \mathrm{kg})$, or a mixture of (propolis $2 \mathrm{~g} / \mathrm{kg}+$ digestarom $150 \mathrm{mg} / \mathrm{kg}$ ) or without any diet supplementation with the vaccine or without any diet supplementation without the vaccine. Alanine Transaminase (ALT), Aspartate Aminotransferase (AST), Total Protein and albumin levels were estimated using commercial kits. The result revealed that dietary supplementation with propolis and /or digestarom caused significant $(P \leq 0.05)$ increases in blood plasma levels of total protein, globulin, levels of albumin, and significantly reduce $(P \leq 0.05) A L T$ and AST with or without heat stress as compared to their control groups, while there was a significant reduction in levels of total protein, albumin, globulin ( $P \leq 0.05)$, and significantly increase $(P \leq 0.05$ in level of AST and ALT. It has concluded that providing broiler's diets with propolis alone or in combination with digestarom are effective in reducing the adverse effects of heat stress in broilers especially the mixture of propolis with digestarom, which gave the best result.
\end{abstract}

Keywords: Albumin, AST, ALT, Broiler, Digestarom, Propolis.

\section{Introduction}

Heat stress is one of the serious problems affecting poultry breeding and production (1). Broiler chickens are perform well in suitable ambient temperature range 10 and $26 \mathrm{c}^{\circ}$ (2). Broiler chicks appear more sensitive to thermal stress than other bird due to their greater metabolic activity (3). The detrimental effects of heat stress as high mortality, decreased feed intake, lower body weight gain and poor feed efficiency are common in broilers subjected to heat stress (4) moreover, oxidative stress in cells, as a consequence of increased free radical generation reactive oxygen species (ROS) and reflected in increases body temperature (5) moreover HS have immunosuppressant effect and dramatic physiological change in chicken organs (6). Several methods are available to alleviate the effect of high environmental temperature on poultry and as it is impractical and very expensive to cool animal buildings, focused on diet manipulations are one of the solutions which proven their success in ameliorating the negative impact on stressed chickens (7). Propolis is an adhesive, dark yellow to brown colored balsam that smells like resin. It is collected from the buds, leaves and similar 


\section{Al-Qadisiyah Journal of Veterinary Medicine Sciences \\ (P-ISSN 1818-5746/ E-ISSN 2313-4429) \\ www.qu.edu.iq/journalvm}

parts of trees and plants by bees and mixed with their wax (8). Propolis is rich in flavonoid, phenolic acid and terpenoid contents (9) and flavonoids known as antioxidant (10). Propolis supplementation is used in poultry diets because of its antioxidative, cytostatic, anti-mutagenic and immunomodulatory properties

Phytogenic feed additives are plant extracts originating from the leaves, roots, tubers or fruits of herbs, spices or other plants are used as natural alternatives to antibiotic, having popularity within the feed industry as growth promoters, antioxidant activities ,stimulate immune function and their safety wide rang with fewer hazards. (11).

\section{Materials and Methods}

\section{Ethical approval}

The Animal Ethical Committee of Veterinary Medicine College, University of Al-Qadisiyah, Iraq, has approved the present study under permission No: 295

\section{Experimental broilers}

In this study, three hundred, one -day-old broiler chicks (Ross-308) from a commercial hatchery, Al-Zahra hatchery Al-Qadisiyah province, were used. Chicks they weighed at incubating with (45-50) g. blood samples collected from heart puncture from ten chickens of each group at the end of experiment (42d). Sera used for estimating the total protein, albumin, globulin and liver enzymes (AST, ALT) (indirect method).

The chicks were divided in to two separated room for two trials (150birds) for each TN and $\mathrm{HS}$, each room then being subdivided in to five partitions by plastic obstructions, representing5 treated groups $(n=30$ chicks)for each group, they were put in floor pens provided with wood-shavings litter and lightening period of $23 \mathrm{~h}$. /day throughout the experimental period.

\section{Nutritional Regimes}

a. Composition of experimental diet Starter: 1 to 21 days
Table (1): Feed constituents of starter basal experimental diet.

\begin{tabular}{|c|c|c|}
\hline Constituents & Quantity / ton & Percentage (\%) \\
\hline Corn & $465 \mathrm{Kg}$ & $46.5 \%$ \\
\hline Wheat & $200 \mathrm{Kg}$ & $20 \%$ \\
\hline Soy bean meal & $300 \mathrm{Kg}$ & $30 \%$ \\
\hline Calcium & $17 \mathrm{Kg}$ & $1.7 \%$ \\
\hline Premix $1 \%$ & $15 \mathrm{Kg}$ & $1.5 \%$ \\
\hline Salt & $2 \mathrm{Kg}$ & $0.2 \%$ \\
\hline Mycofix select & $1 \mathrm{Kg}$ & $0.1 \%$ \\
\hline Energy \% & \multicolumn{2}{|c|}{2940} \\
\hline Protein \% & \multicolumn{2}{|c|}{20.9} \\
\hline
\end{tabular}

b. Final: It was used from 22 days until the finishing the experiment 45 days composed of the following:

Table (2): Feed constituents of final diet.

\begin{tabular}{|l|l|l|}
\hline Constituents & $\begin{array}{l}\text { Quantity } \\
\text { ton }\end{array}$ & $\begin{array}{l}\text { Percentage } \\
(\%)\end{array}$ \\
\hline Corn & $500 \mathrm{Kg}$ & $50 \%$ \\
\hline Wheat & $200 \mathrm{Kg}$ & $20 \%$ \\
\hline Soy bean meal & $265 \mathrm{Kg}$ & $26.5 \%$ \\
\hline Calcium & $17 \mathrm{Kg}$ & $1.7 \%$ \\
\hline Premix 1\% & $15 \mathrm{Kg}$ & $1.5 \%$ \\
\hline Salt & $2 \mathrm{Kg}$ & $0.2 \%$ \\
\hline Mycofix select & $1 \mathrm{Kg}$ & $0.1 \%$ \\
\hline Energy \% & 2970 & \\
\hline Protein \% & 19.6 \\
\hline
\end{tabular}

\section{Experimental design}

Thermo neutral (TN) groups reared under the usual heat program which was starting at $33^{\circ} \mathrm{C}$ then was gradually reduced to $2-3^{\circ} \mathrm{C}$ per week, reaching $21^{\circ} \mathrm{C}$; and maintained until the end of the study.

G1: group offered a corn-soybean meal basal diet with propolis $2 \mathrm{~g} / \mathrm{kg}$ diet along 42 days.

G2: group offered a corn-soybean meal basal diet supplemented with Digestrom ${ }^{\circledR} 150 \mathrm{~g} / \mathrm{ton}$ along 42 days.

G3: group offered a corn-soybean meal basal 1 diet supplemented with (propolis $2 \mathrm{gm} / \mathrm{kg}$ diet $+150 \mathrm{~g} /$ ton $\left(\right.$ Digestrom $\left.^{\circledR}\right)$ along 42 days.

G4: Control group offered a corn-soybean only basal diet.

G5: Control (neither vaccinated nor supplemented) group.

Heat stress, (HS) groups were beginning at $33 \pm 2{ }^{\circ} \mathrm{C}$ and maintained all over the study 
(42 day). The design of the experiments as follow:

HG1: group offered a corn-soybean meal basal diet with propolis $2 \mathrm{gm} / \mathrm{kg}$ diet throughout the duration of the experiment.

HG2: group offered a corn-soybean meal basal diet supplemented with Digestarom150gm/ton throughout of the duration of the experiment.

HG3: group offered a corn-soybean meal basal diet 1 supplemented with (propolis $2 \mathrm{~g} / \mathrm{kg}$ diet $+150 \mathrm{~g} /$ ton $\quad\left(\right.$ Digestrom $^{\circledR}$ ) throughout of the duration of the experiment.

HG4: Control group offered a corn-soybean meal basal diet without supplementation.

HG5: Control (neither vaccinated nor supplemented) group.

\section{Blood Sampling}

Blood samples were collected at 42 day from jugular vein using disposable syringe, and then added to test tubes without anticoagulant, left in room temperature for 2 hrs. then centrifuged for $10 \mathrm{~min}$ at $(3000$ rpm). After that, serum separated immediately and kept at $4{ }^{\circ} \mathrm{C}$ until assayed.

Total Protein, Albumin, and Globulin levels:

\section{Results}

Effects of different treatments and group in total protein $(\mathrm{g} / \mathrm{dl})$ at $\mathbf{4 0}$ days old broiler chicken.

Results presented in Tables (4) and (5), appear the effect of dietary additive propolis and/or digestarom in the mean value of concentration of serum total protein of broiler at day 40 old subjected to heat stress. There were significant increase $(\mathrm{P}<0.05)$ in $\mathrm{TN}$ treated groups, as well as, in HS treated groups and TG3, TG1 then TG2 in comparing with TG4, TG5 control groups values are $(4.837 \pm 0.08 ; \quad 4.069 \pm 0.06$; $3.838 \pm 0.02 ; \quad 3.718 \pm 0.093 ; . \quad 272 \pm 0.14)$
Plasma total protein was detected according to Bayourat (Biuret technique) using a private kit (RANDOX) (12). The spectrophotometric technique was used to determine, plasma total protein and albumen.

\begin{abstract}
Albumin level:
Albumin concentrations measured using (Bromocresol Green) to estimate the level of albumin in the serum by private kit (TC).
\end{abstract}

\section{Globulin level:}

Globulin level measured indirectly, depending on measuring the concentration of total protein and albumin in the serum.

Globulin magnitude $\mathrm{g} / \mathrm{dL}=$ Total protein con. -Albumin conc.

Estimation of liver enzyme: (ALT and AST)

Asparate amino transefrase and alanine amino transefrase enzymes activities were measured by using enzymatic kit. This test was done according to instructions of manufactures manual. Component of Aspartate aminotransferase Kit (AST) and (ALT): used to measure the activity of these Yeasts commercial Kit (RANDOX) they were carried out according to the manufactures instruction. The Kit is used only in the event that the spectrophotometer device dose not read wave length $(546 \mathrm{~nm})$. Examination was conducted following the instruction recorded of laboratory.

respectively, higher values found in TG3 . In HS groups significant increase $(\mathrm{P}<0.05)$ in the mean value of G3, G1, G2 in comparing with G4, G5 with values (3.908 \pm 0.03 ; $3.689 \pm 0.042 ; 3.506 \pm 0.02 ; \quad 3.336 \pm 0.08$; $2.995 \pm 0.04)$ respectively with highest elevation showed in G3 .Comparing among all exposed to heat stress groups, each with the analogous group of $\mathrm{TN}$ revealed that there were significant decrease $(\mathrm{P}<0.05)$ in the mean values between HG1, TG1; HG2 ,TG2; HG3 and TG3 and also between HG4,TG4. 


\section{Al-Qadisiyah Journal of Veterinary Medicine Sciences \\ (P-ISSN 1818-5746/ E-ISSN 2313-4429) \\ www.qu.edu.iq/journalvm}

Table (3): effects of different treatments and group in total protein (g/dl) at 40 days old

\begin{tabular}{|c|c|c|c|}
\hline \multirow{2}{*}{ Groups } & \multicolumn{2}{|c|}{ Mean $\mathbf{\text { SE }}$} & \multirow{2}{*}{ LSD value } \\
\cline { 2 - 3 } \multirow{2}{*}{ G1 } & Thermo neutral (TN)group & Heat stress( HS) & 0.247 \\
\hline \multirow{2}{*}{ G2 } & $\begin{array}{c}4.069 \pm 0.06 \\
\mathrm{Ba}\end{array}$ & $\begin{array}{c}3.689 \pm 0.04 \\
\mathrm{Bb}\end{array}$ & 0.127 \\
\hline \multirow{2}{*}{ G3 } & $\begin{array}{c}3.838 \pm 0.02 \\
\mathrm{Ba}\end{array}$ & $\begin{array}{c}3.506 \pm 0.02 \\
\mathrm{BCb}\end{array}$ & 0.286 \\
\hline \multirow{2}{*}{ G4 } & $\begin{array}{c}4.837 \pm 0.08 \\
\mathrm{Aa}\end{array}$ & $\begin{array}{c}3.908 \pm 0.03 \\
\mathrm{Ab}\end{array}$ & 0.416 \\
\hline \multirow{2}{*}{ G5 } & $\begin{array}{c}3.718 \pm 0.09 \\
\mathrm{Ba}\end{array}$ & $\begin{array}{c}3.336 \pm 0.08 \\
\mathrm{Ca}\end{array}$ & 0.5 \\
\hline LSD value & $3.272 \pm 0.14$ & $\begin{array}{c}2.995 \pm 0.04 \\
\mathrm{Da}\end{array}$ & \\
\hline
\end{tabular}

Number of samples: 5 from each group. G1: administrated propolis $2 \mathrm{~g} / \mathrm{kg}$, G2: digestarom150mg/kg, G3: administrated mix (propolis +digestarom), G4: Control Positive, G5: Control Negative. Means having different capital letters (in columns) and small letters (in rows) are significant difference $(\mathbf{P}<\mathbf{0 . 0 5})$. LSD: less significant differences.

Effects of different treatments and group in Albumin ( $\mathrm{g} / \mathrm{dl})$ at 40 days old.

Tables (4) and (6) summarized the mean values of concentration of albumin in $\mathrm{TN}$ and HS groups. It was recorded of significant increases $(\mathrm{P}<0.05)$ in the values of $\mathrm{TN}$ as well as HS groups in comparing witty non treated control groups with or without heat stress, TG3,TG1then TG2 in comparing with TG4,TG5 control groups values are $(2.774 \pm 0.04 ; \quad 2.174 \pm 0.04 ; \quad 2.064 \pm 0.007$ $(2.028 \pm 0.07 ; 1.728 \pm 0.08)$ respectively and TG3 have the higher value, while in HS groups significant increase $(\mathrm{P}<0.05)$ in the mean value of G3,G1,G2in comparing with G4,G5 with values $(2.034 \pm 0.01 ; 1.897 \pm 0.03$; $1.809 \pm 0.02 ; \quad 1.658 \pm 0.02 ; \quad 1.52 \pm 0.04$ ) respectively, higher values found inHG3.. Insignificant difference was found between HG1 and HG2.In comparing all of heat stressed groups with all of homologous TN groups revealed the presence of significant decreases $(\mathrm{P}<0.05)$ of the values between HG1， TG1;HG2 ,TG2 ;HG3 ,TG3 and between control groups HG4, TG4 and HG5 ,TG5.

Table (4): effects of different treatments and group in Albumin (g/dl) at 40 days old

\begin{tabular}{|c|c|c|c|}
\hline \multirow{2}{*}{ Groups } & \multicolumn{2}{|c|}{ Mean \pm SE } & \multirow{2}{*}{ LSD value } \\
\cline { 2 - 4 } & Thermo neutral TN & Heat stress HS & 0.172 \\
\hline \multirow{2}{*}{ G1 } & $\begin{array}{c}2.174 \pm 0.04 \\
\mathrm{Ba}\end{array}$ & $\begin{array}{c}1.897 \pm 0.03 \\
\mathrm{Bb}\end{array}$ & 0.084 \\
\hline \multirow{2}{*}{ G3 } & $\begin{array}{c}2.064 \pm 0.007 \\
\mathrm{Ba}\end{array}$ & $\begin{array}{c}1.809 \pm 0.02 \\
\mathrm{Bb}\end{array}$ & 0.163 \\
\hline \multirow{2}{*}{ G4 } & $\begin{array}{c}2.774 \pm 0.04 \\
\mathrm{Aa}\end{array}$ & $\begin{array}{c}2.034 \pm 0.01 \\
\mathrm{Ab}\end{array}$ & 0.262 \\
\hline \multirow{2}{*}{ G5 } & $\begin{array}{c}2.028 \pm 0.07 \\
\mathrm{Ba}\end{array}$ & $\begin{array}{c}1.658 \pm 0.02 \\
\mathrm{Cb}\end{array}$ & 0.311 \\
\hline LSD value & $\begin{array}{c}1.728 \pm 0.08 \\
\mathrm{Ca}\end{array}$ & $\begin{array}{c}1.52 \pm 0.04 \\
\mathrm{Db}\end{array}$ & 0.117 \\
\hline
\end{tabular}

G1: administrated propolis $2 \mathrm{~g} / \mathrm{kg}$, G2: digestarom150mg/kg, G3: administrated mix (propolis +digestarom), G4: Control Positive, G5: Control Negative. Means having different capital letters (in columns) and small letters (in rows) are significant difference $(\mathbf{P}<0.05)$. LSD: less significant differences

Effects of different treatments and group in Globulin (g/dl) at 40 days old.

Globulin concentration at day 40 in $\mathrm{TN}$ groups showed significant increases $(\mathrm{P}<0.05)$ in the values of TN and HS treated groups with or without heat stress. TG3, TG1 and TG2 in comparing with TG4 and TG5. values are $(2.062 \pm 0.07 ; \quad 1.895 \pm 0.02$; $1.774 \pm 0.02 ; \quad 1.69 \pm 0.06 ; \quad 1.544 \pm 0.06$ respectively. Insignificant differences were 


\section{Al-Qadisiyah Journal of Veterinary Medicine Sciences \\ (P-ISSN 1818-5746/ E-ISSN 2313-4429) \\ www.qu.edu.iq/journalvm}

noticed betweenTG2and TG4. Heat stressed

compared to G4 ,G5

$(1.677 \pm 0.06$ groups G3, G1, G2 and values are $1.475 \pm 0.02$ ) respectively. $(1.874 \pm 0.03 ; \quad 1.792 \pm 0.02 ; 1.696 \pm 0.01) \quad$ in

Table (5): Effects of different treatments and group in Globulin (g/dl) at 40 days old

\begin{tabular}{|c|c|c|c|}
\hline \multirow{2}{*}{ Groups } & \multicolumn{2}{|c|}{ Mean \pm SE } & \multirow{2}{*}{ LSD value } \\
\hline & Normal group & Heat stress & \\
\hline G1 & $\begin{array}{c}1.895 \pm 0.02 \\
\mathrm{Aba}\end{array}$ & $\begin{array}{c}1.792 \pm 0.02 \\
\mathrm{ABa}\end{array}$ & 0.118 \\
\hline G2 & $\begin{array}{c}1.774 \pm 0.02 \\
\mathrm{BCa}\end{array}$ & $\begin{array}{c}1.696 \pm 0.01 \\
\mathrm{Ba}\end{array}$ & 0.097 \\
\hline G3 & $\begin{array}{c}2.062 \pm 0.07 \\
\mathrm{Aa}\end{array}$ & $\begin{array}{c}1.874 \pm 0.03 \\
\mathrm{Aa}\end{array}$ & 0.258 \\
\hline G4 & $\begin{array}{c}1.69 \pm 0.06 \\
\mathrm{BCa} \\
\end{array}$ & $\begin{array}{c}1.677 \pm 0.06 \\
\mathrm{Ba}\end{array}$ & 0.308 \\
\hline G5 & $\begin{array}{c}1.544 \pm 0.06 \\
\mathrm{Ca}\end{array}$ & $\begin{array}{c}1.475 \pm 0.02 \\
\mathrm{Ca}\end{array}$ & 0.236 \\
\hline LSD value & 0.232 & 0.158 & \\
\hline
\end{tabular}

Number of samples: 5 from each group. G1: administrated propolis 2 g/kg, G2: digestarom150mg/kg, G3: administrated mix (propolis +digestarom), G4: Control Positive, G5: Control Negative. Means having different capital letters (in columns)

Effects of different treatments in level of Aspartate transaminase AST (g/d) in 40 days old broilers at TN and HS conditions.

Levels of AST were determined in plasma of experimental broilers at 42 day of age. The results summarized in Tables (4) and (8) which indicated that there was significant decreased $\mathrm{P}<0.05$ in the level of AST in sera of treated $\mathrm{TN}$ and $\mathrm{HS}$ treated groups in comparing with non-treated control groups. TN groups G3, G1, G2 value are $(6.74 \pm 0.2$; $7.32 \pm 0.15 ; 7.5 \pm 0.2$ ) respectively, while cont. G4, G5 $(8.58 \pm 0.15 ; 7.98 \pm 0.06)$ respectively and the lowest level was found in TG3.Comparing within HS groups appear the presence of a significant significantly decreases $(\mathrm{P}<0.05)$ in the level of AST, G3, G1, G2 values are $(7.34 \pm 0.16 ; 8.04 \pm 0.19$; $8.44 \pm 0.17)$ respectively in comparing with G4,G5 (9.36 $\pm 0.2 ; 9.04 \pm 0.16)$,also significant decrease between HG2 and HG1. Comparing all of heat stressed groups with all homologous TN groups revealed the presence of significant increases $(\mathrm{P}<0.05)$ of the levels values of AST between HG1, TG1; HG2, TG2, and HG3, TG3.also between control groups HG4, TG4, HG5 and TG5. The data also showed decrease in the level of AST in all HS groups in comparing to control TN TG4 and TG5.

Table (6): Effects of different treatments and group in AST (g/dl) at 40 days old.

\begin{tabular}{|c|c|c|c|}
\hline \multirow{2}{*}{ Groups } & \multicolumn{2}{|c|}{ Mean \pm SE } & \multirow{2}{*}{ LSD value } \\
\cline { 2 - 4 } & $\mathbf{T N}$ & Heat stress HS & \multirow{2}{*}{0.569} \\
\hline \multirow{2}{*}{ G1 } & $\begin{array}{c}7.32 \pm 0.15 \\
\mathrm{Cb}\end{array}$ & $\mathrm{Ba}$ & 0.19 \\
\hline \multirow{2}{*}{ G3 } & $\begin{array}{c}7.5 \pm 0.2 \\
\mathrm{BCb}\end{array}$ & $\begin{array}{c}8.44 \pm 0.17 \\
\mathrm{Ba}\end{array}$ & 0.742 \\
\hline \multirow{2}{*}{ G4 } & $\begin{array}{c}6.74 \pm 0.2 \\
\mathrm{Da}\end{array}$ & $\begin{array}{c}7.34 \pm 0.16 \\
\mathrm{Ca}\end{array}$ & 0.649 \\
\hline \multirow{2}{*}{ G5 } & $\begin{array}{c}8.58 \pm 0.15 \\
\mathrm{Ab}\end{array}$ & $\begin{array}{c}9.36 \pm 0.2 \\
\mathrm{Aa}\end{array}$ & 0.714 \\
\hline LSD value & $\begin{array}{c}7.98 \pm 0.06 \\
\mathrm{Bb}\end{array}$ & $\begin{array}{c}9.04 \pm 0.16 \\
\mathrm{Aa}\end{array}$ & 0.399 \\
\hline
\end{tabular}

Number of samples: 5 from each group. G1: administrated propolis $2 \mathrm{~g} / \mathrm{kg}$, G2: digestarom150mg/kg, G3: administrated mix (propolis +digestarom), G4: Control Positive, G5: Control Negative. Means having different capital letters (in columns) and small letters (in rows) are significant difference $(\mathbf{P}<0.05)$. LSD: less significant differences. 


\section{Al-Qadisiyah Journal of Veterinary Medicine Sciences \\ (P-ISSN 1818-5746/ E-ISSN 2313-4429) \\ www.qu.edu.iq/journalvm}

Effects of different treatments in level of alanine transaminase ALT (g/dl) in 40 days old broilers at $\mathrm{TN}$ and $\mathrm{HS}$ conditions:

Levels of ALT were determined in plasma of experimental broilers 42 days of age. The results summarized in (tab. 4.9) which indicated that there was significant decreased $(\mathrm{P}<0.05)$ in the level of ALT in sera of treated groups with or without HS. TN groups G3, G1, G2 values are $(4.53 \pm 0.15$; $4.86 \pm 0.091 ; 4.88 \pm 0.15)$ respectively, and lowest level was found in G3 ,while cont. G4 and G5 $(5.96 \pm 0.2 ; 5.4 \pm 0.2)$ respectively .Comparing within HS groups appear significantly decreases $(\mathrm{P}<0.05)$ in the level of ALT, G3, G1, G2 in comparing to G4, G5 with values $(5.44 \pm 0.13 ; 6.44 \pm 0.19 ; 6.86 \pm 0$. $7.36 \pm 0.27 .1 \pm 0.3)$ respectively with lowest level in G3. Comparing all of heat stressed groups with all homologous TN groups revealed the presence of significant increases $(\mathrm{P}<0.05)$ of the levels values of ALT between HG1, TG1; HG2, TG2; HG3 ,TG3, also among control groups HG4, TG4, HG5 and TG5. The data also showed significant increase in the level of ALT inHG1 and HG2 of HS groups in comparing to thermo-neutral control groups TG4 and TG5. While HG3 showed significant decrease in the level of ALT compared to them.

Table (7): Effects of different treatments and group in ALT (g/dl) at 40 days old

\begin{tabular}{|c|c|c|c|}
\hline \multirow{2}{*}{ Groups } & \multicolumn{2}{|c|}{ Mean \pm SE } & \multirow{2}{*}{ LSD value } \\
\hline & Normal group & Heat stress & \\
\hline G1 & $\begin{array}{c}4.88 \pm 0.15 \\
\mathrm{BCb}\end{array}$ & $\begin{array}{c}6.44 \pm 0.19 \\
\mathrm{Ba}\end{array}$ & 0.564 \\
\hline G2 & $\begin{array}{c}4.86 \pm 0.09 \\
\mathrm{BCb}\end{array}$ & $\begin{array}{c}6.86 \pm 0.2 \\
\text { Aba }\end{array}$ & 0.644 \\
\hline G3 & $\begin{array}{c}4.53 \pm 0.15 \\
\mathrm{Cb}\end{array}$ & $\begin{array}{c}5.44 \pm 0.13 \\
\mathrm{Ca}\end{array}$ & 0.477 \\
\hline G4 & $\begin{array}{c}5.96 \pm 0.2 \\
\mathrm{Ab}\end{array}$ & $\begin{array}{c}7.36 \pm 0.2 \\
\mathrm{Aa}\end{array}$ & 0.769 \\
\hline G5 & $\begin{array}{c}5.4 \pm 0.2 \\
\mathrm{Bb}\end{array}$ & $\begin{array}{c}7.1 \pm 0.3 \\
\mathrm{ABa}\end{array}$ & 0.862 \\
\hline LSD value & 0.522 & 0.692 & \\
\hline
\end{tabular}

Number of samples: 5 from each group. G1: propolis at a dose $2 \mathrm{~g} / \mathrm{kg}$, G2: digestarom150g/ton, G3: administrated mix (propolis +digestarom), G4: Control Positive, G5: Control Negative. Means having different capital letters (in columns) and small letters (in rows) are significant difference $(\mathbf{P}<\mathbf{0 . 0 5})$. LSD: less significant

\section{Discussion}

Serum IgG concentration in the chickens fed propolis supplementation reared under both normal and high temperatures were higher than those fed the control diets, indicating that propolis could modulate humeral immunity and supplementation activates the immune system in chickens, increasing macrophage increase activity of B-lymphocytes, which would be able to produce immunoglobulins. Hence, the increased levels of IgG in broilers fed dietary BG are probably related to the B-lymphocyte stimulation by cytokines (13). The increased levels in birds treated with propolis may be related to the stimulation of B lymphocytes by increasing macrophage activity and increasing concentrations of cytokines such as interleukin-1, interleukin-2, and interleukin-4 (14). These cytokines further stimulate B lymphocytes to become plasma cells, producing immunoglobulins (15). These effects could be attributed to the benzene and flavonoids constituents of propolis, found that stressors are able to enhance the immunoglobulin levels even at $24 \mathrm{~h}$ after subjection to the stressing conditions. In the present study, the levels of in plasma immunoglobulin levels were decreased in the chickens housed at HSD. These results may be associated with decreased immunological memory, therefore leading to an increase in the susceptibility of 


\section{Al-Qadisiyah Journal of Veterinary Medicine Sciences \\ (P-ISSN 1818-5746/ E-ISSN 2313-4429) \\ www.qu.edu.iq/journalvm}

chickens to pathogenic challenge. These findings showed that serum globulin concentration in the chickens fed dietary propolis supplementation reared under both normal and high temperatures were higher than those fed the control diets, indicating that propolis could modulate humeral immunity and activates the immune system in chickens (16) demonstrated that serum total protein and globulin levels were significantly increased in propolis $(2 \mathrm{~g} / \mathrm{kg})$. In addition, serum total protein and globulin levels were significantly increased in chickens fed with $2 \%$ propolis and this agree (17) and under thermo-neutral temperatures. Finally, anti-oxidizing properties of propolis considered to improve lipid metabolism, liver morphological structures and biological functions (18). This result is in agreement with the studies (19) who concluded that dietary natural antioxidants are the first strategy against the unpleasant consequences of heat stress on the poultry production. Level of aspartate aminotransferase (AST) and alanine aminotransferase (ALT) were determined in plasma of experimental broilers 42 day of age, their level in plasma are associated with cellular injury in broilers exposed to high temperature Table (4.10 and Table 4.11 where there are elevation of these two enzymes in HS groups compared to TN groups and this results are in line of many researchers who indicated that these enzymes and other enzymes are used as tools for differential diagnosis in the clinical biochemistry and, the plasma levels of different enzymes are affected as animals or even human subjected to stress (20) the results of present study agreement (21) who indicated that exposure to high ambient temperature markedly increased plasma ALT levels in the broilers after different periods of heat stress, and its level increased significantly as the duration of heat stress was increased. Heat challenge increases body temperature, which consequently leads to an increase in free radical production and subsequent oxidative damage. Increases in plasma LDH, AST, ALT, and CK prolonged heat stress results in a dramatic physiological change in chicken organs and these changes might be used as indicator of heat stress. Since the bulk of each enzyme is located in different tissues, their abnormal levels in the blood plasma can give an indication to specific muscle or organ damages and activity partly attributed to cellular damage (22). Consequence of heat stress under heat stress conditions, the activities of CK, ALT and AST were generally high, on other hands dietary supplementation of propolis $2 \mathrm{~g} / \mathrm{kg}$ of diet or prebiotic $150 \mathrm{~g} / \mathrm{ton}$ or combination of two significantly reduced the two enzymes activity in broiler chickens and this result may reflecting that propolis may regal ate liver metabolism (18). Showed a significant decrease in serum alanine transaminase activity in Japanese quail given $1 \mathrm{~g} / \mathrm{kg}$ of propolis compared with birds treated with flavomycin. Reduced enzyme activity could indicate that propolis is able to reduce tissue damage and prevent the leakage of enzymes through cellular membranes and due to its antioxidative function (23). Concerning the role of combination of propolis and prebiotic, the result revealed better than each of them alone and the level decreased significantly $(\mathrm{p}<0.05)$ in birds fed mixed supplementations compared to the control group due to improved liver function and reduced liver damage. This result is in agreement with the studies of (19), whom concluded that dietary natural antioxidants are the first strategy against the unpleasant consequences of heat stress on the quality of poultry meat. The protective effect of propolis upon liver could be due to antioxidant contents of some flavonoids, which play a role as antioxidant against oxidative material, which caused damage to liver (24). In the current study, elevated activity of plasma AST, ALT, after 6- of chronic heat exposure treatment was observed, suggesting possible liver and muscular oxidative injuries in broiler breeders. 


\section{Al-Qadisiyah Journal of Veterinary Medicine Sciences \\ (P-ISSN 1818-5746/ E-ISSN 2313-4429) \\ www.qu.edu.iq/journalvm}

\section{References}

1-Chiang W, Booren A, Strasburg G. The effect of heat stress on thyroid hormone response and meat quality in turkeys of two genetic lines. Meat science, (2008).80(3), 615-622.

2-Filizciler M, Çerci İH, Tatli P. Effects of night feeding on SPF (Specific Pathogen Free) white egg layers under heat stress. Turkish Journal of Vet. and Animal Sci. (2002) 26(3), 439-446.

3-Sohail MU, Hume ME, Byrd JA, Nisbet DJ, Ijaz A, Sohail A, Shabbir MZ, Rehman H. Effect of supplementation of prebiotic mannanoligosaccharides and probiotic mixture on growth performance of broilers subjected to chronic heat stress, Poult. Sci., (2012); 91, 2235-2240

4-Akbarian A, Michiels J, Golian A, Buyse J, Wang Y, De Smet S. Gene expression of heat shock protein 70 and antioxidant enzymes, oxidative status, and meat oxidative stability ofcyclically heatchallenged finishing broilers fed Origanumcompactum and Curcuma xanthorrhiza essential oils, Poult Sci., (2014); 93, 1930-1941.

5-Altan Ö, Pabuçcuoğlu A, Altan A, Konyalioğlu S, Bayraktar H. Effect of heat stress on oxidative stress, lipid peroxidation and some stress parameters in broilers. British poultry science, (2003); 44(4), 545-550.

6-Attia YA, Hassan SS. Broiler tolerance to heat stress at various dietary protein/energy levels. Eur. Poult. Sci, (2017); 81, 10-1399.

7-Konca Y, Kirkpinar F, Mert S. Effects of mannanoligosaccharides and live yeast in diets on the carcass, cut yields, meat composition and colour of finishing turkeys. Asian Australas. J. Anim. Sci, (2009); 22(4), 550-556.

8-Seven PT. The effects of dietary Turkish propolis and vitamin $\mathrm{C}$ on performance, digestibility, egg production and egg quality in laying hens under different environmental temperatures. AsianAustralasian Journal of Animal Sciences, (2008); 21(8), 1164-1170.

9-Wang Z, Bovik AC, Sheikh HR, Simoncelli EP. Image quality assessment: from error visibility to structural similarity. IEEE transactions on image processing, (2004); 13(4), 600-612.

10-Havsteen BH. The biochemistry and medical significance of the flavonoids. Pharmacology \& therapeutics, (2002); 96(2-3), 67-202.

11-Jamroz D, Wertelecki T, Houszka M, Kamel C. Influence of diet type on the inclusion of plant origin active substances on morphological and histochemical characteristics of the stomach and jejunum walls in chicken. Journal of Animal Phys. and Animal Nutrition, (2006); 90(5-6), 255-268.

12-Cannon FC, Dixon RA, Postgate JR, and Primrose SB. Plasmids formed in nitrogen - fixing Escherichia coli Klebsiella pneumoniae

Hybrids. Microbiology, (1974); 80(1), 241-251

13-Hosseini SE, Wahid MA. Hydrogen production from renewable and sustainable energy resources: promising green energy carrier for clean development. Renewable and Sustainable Energy Reviews, (2016); 57, 850-866.

14-Park C, Miller R, Laflen D, Neb C, Ivanov J, Bennett B, Huggins R. Imaging dispersion curves of passive surface waves. In SEG technical program expanded abstracts (2004); pp: 1357-1360. Society of Exploration Geophysicists.

15-Dimov V, Ivanovska N, Manolova N, Bankova V, Nikolov N, Popov S. Immunomodulatory action of propolis. Influence on anti-infectious protection and macrophage function. Apidologie (1991); 22(2),155-

16-Abdel-Rahman MA, Mosaad GM. Effect of propolis as additive on some behavioural patterns, performance and blood parameters in Muscovy broiler ducks. Journal of Advanced Veterinary Research, (2013); 3(2), 64-68.

17-Omar Sharifuddin Syed-Ikhsan S, Row land F. Knowledge management in a public organization: a study on the relationship between organizational elements and the performance of knowledge transfer. Journal of knowledge management, (2004); 8(2), 95-111.

18-Babińska I, Kleczek K, Makowski W, Szarek J. Effect of feed supplementation with propolis on liver and kidney morphology in broiler chickens. Pakistan Veterinary Journal, (2013); 33(1), 1-4.

19-Patra RC, Rautray AK, Swarup D. Oxidative stress in lead and cadmium toxicity and its amelioration. Vet. Med. international, (2011).

20-Mashiko T, Umeda T, Nakaji S, Sugawara, K. Effects of exercise on the physical condition of college rugby players during summer training camp. British journal of sports medicine, (2004); 38(2), 186-190.

21-Brancaccio P, Maffulli N, Limongelli FM. Creatine kinase monitoring in sport med. British med. bulletin, (2007); 81(1), 209-230.

22-Pech-Waffenschmidt V. The effect of heat stress conditions on performance, physiology, and blood chemistry of laying hens of different feathering types, and nutritional considerations to improve the heat resistance. (1992).

23-Newairy AA, Abdou HM. Effect of propolis consumption on hepatotoxicity and brain damage in male rats exposed to chlorpyrifos. African Journal of Biotechnology, (2013); 12(33).

24-El-Neney BA, El-Kholy KH. Effect of natural additive (bee pollen) on immunity and productive and reproductive performances in rabbits. 1-Growth performance, digestive and immune responses. Egypt. Poultry. Sci. J, (2014); 34, 579. 